\title{
A CLINICAL TRIAL OF HYDROCORTISONE IN THE PREVENTION OF TRANSFUSION THROMBOPHLEBITIS
}

\author{
P. B. Clark, M.B., F.R.C.S.* \\ Lately Surgical Registrar
}

A. Polak, M.D., M.R.C.P.

Lately Senior Medical Registrar

John Hajnal, M.A.

Ashford Hospital, Middlesex

Thrombophlebitis occurs in more than 50 per cent. of patients receiving intravenous infusions. Its incidence was reduced to 32 per cent. in a recent trial of plastic drip sets (Medical Research Council Blood Transfusion Research Committee, 1957), but these are not in general use in this country. It can be virtually abolished by stopping all infusions after eight hours (Bolton Carter, I95 I), but this is seldom practicable. The possibility of suppressing it by adding ro mg. hydrocortisone alcohol to each litre of infusion fluid was suggested in a previous communication (Polak, 1956). This possibility has been tested by the clinical trial reported here.

\section{Methods}

One hundred and fifty consecutive infusions in four general surgical wards were included in the trial. For each infusion a numbered bottle of additive solution was issued, $2 \mathrm{ml}$. of which was added to each litre of fluid infused (excepting blood). Of the 150 bottles of additive solution, 75 contained $100 \mathrm{mg}$. hydrocortisone in $20 \mathrm{ml}$. of 50 per cent. ethyl alcohol, and 75 contained $20 \mathrm{ml}$. of 50 per cent. ethyl alcohol only. The observers did not know until the end of the trial which bottles contained the hydrocortisone. They recorded the duration of the infusion, the type of needle or cannula inserted and the site and manner of insertion, the type of drip tubing, and the nature of the fluids which were given. They also measured the length of vein which was indurated or over which there was tenderness or redness, and recorded the presence and severity of swelling, so that the result of each infusion

*Present address Manchester Royal Infirmary. could be classified according to the criteria used by the Medical Research Council's Blood Transfusion Research Committee (1957):

' $\mathrm{O}$ '- No reaction, or painless thrombosis without inflammation.

' $M$ '-Mild reaction, with less than 3 in. of vein inflamed.

' $\mathrm{S}$ '-Severe thrombophlebitis, affecting 3 to 6 in. of vein.

' $\mathrm{S}+$ '-Extensive thrombophlebitis, affecting more than 6 in. of vein.

\section{Results}

Forty-two of the records were discarded, either because the infusions lasted less than 24 hours,

Frequency Distribution of Reactions - With THE Two Types of Additive for. Various TOtal Lengths OF INFUSIONS

\begin{tabular}{|c|c|c|c|c|c|c|c|}
\hline \multirow{3}{*}{\multicolumn{2}{|c|}{ 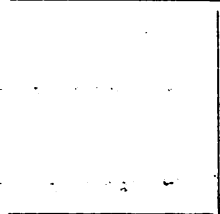 }} & \multirow{3}{*}{$\begin{array}{c}\text { Reac- } \\
\text { tion }\end{array}$} & \multicolumn{5}{|c|}{$\begin{array}{c}\text { Total length of infusion } \\
\text { (hours) }\end{array}$} \\
\hline & & & \multicolumn{2}{|c|}{$24-48$} & \multicolumn{2}{|c|}{$\begin{array}{l}48 \text { or } \\
\text { more }\end{array}$} & \multirow[t]{2}{*}{ Total } \\
\hline & & & No. & $\%$ & No. & $\%$ & \\
\hline \multirow{2}{*}{\multicolumn{2}{|c|}{ Hydrocortisone }} & $\begin{array}{l}\mathbf{S}+ \\
\mathbf{S} \\
\mathbf{M} \\
\mathbf{O}\end{array}$ & $\begin{array}{r}1 \\
2 \\
8 \\
11\end{array}$ & $\begin{array}{r}5 \\
9 \\
36 \\
50\end{array}$ & $\begin{array}{r}14 \\
5 \\
10 \\
5\end{array}$ & $\begin{array}{l}41 \\
15 \\
29 \\
15\end{array}$ & $\begin{array}{r}15 \\
7 \\
18 \\
16\end{array}$ \\
\hline & & Total & 22 & 100 & 34 & 100 & 56 \\
\hline \multirow[t]{2}{*}{ Control } & . & $\begin{array}{l}\mathbf{S}+ \\
\mathbf{S} \\
\mathbf{M} \\
\mathbf{O}\end{array}$ & $\begin{array}{l}2 \\
3 \\
7 \\
5\end{array}$ & $\begin{array}{l}12 \\
18 \\
41 \\
29\end{array}$ & $\begin{array}{r}8 \\
14 \\
8 \\
5\end{array}$ & $\begin{array}{l}23 \\
40 \\
23 \\
14\end{array}$ & $\begin{array}{l}10 \\
17 \\
15 \\
10\end{array}$ \\
\hline & & Total & 17 & 100 & 35 & 100 & 52 \\
\hline
\end{tabular}


or leakage obscured the results, or the additive was accidentally omitted. Of the remaining 108, 56 were records of hydrocortisone-treated cases and 52 of controls. The frequency distribution of the reactions in each of these groups is given in the table. The figures are subdivided according to whether the infusions lasted 24 to 48 hours or more than 48 hours, because liability to thrombophlebitis is known to increase with the duration of the infusion (Bolton Carter, I95I).

When the categories of thrombophlebitis in the table are rated on an arbitrary scale from $\circ$ (no reaction, ' $\mathrm{O}$ ') to 3 (extensive thrombophlebitis, ' $\mathrm{S}+$ '), the mean rating in the hydrocortisone group is 1.37 and in the control group 1.52. The difference, namely 0.15 , has a standard error of 0.2 and is therefore not significant.*

In the trial of plastic drip sets referred to above, the difference between the results obtained with rubber and plastic sets in transfusions lasting over 24 hours was 0.5 when measured on the same scale. This implied a reduction in the incidence of thrombophlebitis from 68 to 42 per cent.

*This analysis relates to all the infusions regardless of duration (i.e., last column of the table). If the duration groups are treated separately and equal weight is given to each group, the ratio of the difference between the hydrocortisone and control infusions to the standard error of this difference is almost the same.
If the effect of hydrocortisone were as great this, the probability that our results might conce it (i.e. the probability of showing a difference $a \frac{3}{8}$ small as ours or smaller), is about 5 per cene A smaller effect would be more readily concealedbut would be of little practical importance in view: of the cost of the drug and the trouble and risf involved in the use of transfusion additives.

\section{Summary}

In a controlled trial, hydrocortisone alcoho $\$$ 1o mg. per litre failed to bring about a significanto reduction in the incidence of transfusion thrombo $\overrightarrow{0}$ phlebitis.

\section{Acknowledgments}

We are grateful to the North West Metró politan Regional Hospital Board for a research. grant, to Upjohn of England Ltd. for a gift hydrocortisone alcohol ('Cortef '), to Mr. O. Di Morris and Mr. J. L. Stephen for permission to carry out this trial in their wards, and to the medical and nursing staff at Ashford and Paddings ton Hospitals for their valuable help.

\section{REFERENCES}

BOLTON CARTER, J. F. (1951), Lancet, ii, 20. MEDICAL RESEARCH COUNCIL BLOOD TRANSFUSION

RESEARCH COMMITTEE (1957), Ibid., i, 595. POLAK, A. (1956), Ibid., i, 484.

\section{DIA BETES}

(Postgraduate Medical Fournal, May 1959)

Price 6s. 6d. post free

ORAL HYPOGLYCAEMIC DRUGS

J. D. H. Slater, M.A., M.B., M.R.C.P.

DIABETES IN CHILDREN

James Robertson, M.B., M.R.C.P.

AETIOLOGICAL FACTORS IN DIABETES

D. A. Pyke, M.D., M.R.C.P.

PLASMA INSULIN ACTIVITY IN DIABETICS

J. Vallance-Owen, M.A., M.D. (Cantab.), M.R.C.P.

\section{AUTONOMIC NEUROPATHY IN DIABETES MELLITUS}

Harry Keen, M.B., M.R.C.P.
SOCIAL PROBLEMS OF THE DIABETIC

Iris Holland Rogers

PREDIABETES-A SYNTHESIS

W. P. U. Jackson, M.A., M.D., M.R.C.P., D.C.H.

THE OCULAR COMPLICATIONS OF DIABETES

P. D. Trevor-Roper, M.A., M.B., B.Chir., F.R.C.S.

THE DETECTION OF LATENT DIABETES

Joan B. Walker, M.D.

THE GLUCOSE TOLERANCE TEST

Joyce D. Baird, M.A., M.B.Ch.B., and Leslie J. P. Duncan, B.Sc., M.B.Ch.B., M.R.C.P.E.

\section{Published by \\ THE FELLOWSHIP OF POSTGRADUATE MEDICINE \\ 60, Portland Place, London, W.1}

